\title{
Postharvest physiology and storage potential of new Chilean raspberry cultivars
}

\author{
Carolina Contreras ${ }^{1}$, Adolfo Hermosilla ${ }^{2}$, Élida Contreras $^{2}$, Paulina Naranjo ${ }^{2}$, Juan Pablo Zoffoli ${ }^{2}$, and \\ Marina Gambardella ${ }^{2 *}$
}

\begin{abstract}
${ }^{1}$ Universidad Austral de Chile, Facultad de Ciencias Agrarias y Alimentarias, Instituto de Producción y Sanidad Vegetal, Isla Teja S/N, Valdivia, Chile.

${ }^{2}$ Pontificia Universidad Católica de Chile, Facultad de Agronomía e Ingeniería Forestal, Vicuña Mackenna 4860, PO Box 7820436, Santiago, Chile. "Corresponding author (mgambardella@uc.cl).
\end{abstract}

Received: 5 October 2020; Accepted: 23 December 2020; doi:10.4067/S0718-58392021000200161

\begin{abstract}
Raspberries (Rubus ideaus L.) are highly perishable and susceptible to rot during storage. An exploratory study of postharvest physiology associated with maturity was carried out for three new Chilean raspberry cultivars: Santa Catalina, Santa Clara and Santa Teresa. Fruit of these cultivars were harvested at three maturity stages based on color: pink (C3), bright red (commercial maturity) (C4) and dark red (C5). Two experiments were carried out to: i) determine postharvest quality and physiological parameters associated with maturity stages in comparison to those fruits of the main $\mathrm{cv}$. Heritage, and ii) evaluate storage potential at 0 and $4{ }^{\circ} \mathrm{C}$ of 'Santa Catalina'. In the first study, fruit quality parameters (such as weight, firmness, color, among others) of all the 'Santa' cultivars were assessed immediately after harvest, and the ethylene production and respiration rates $\left(\mathrm{CO}_{2}\right)$ were recorded for $4 \mathrm{~d}$ at $20^{\circ} \mathrm{C}$. In the second experiment, 'Santa Catalina' was stored at 0 and $4{ }^{\circ} \mathrm{C}$. According to the results of the first experiment, 'Santa Teresa' presented the largest fruit (7.9 g), followed by 'Santa Clara' (5.3 g), 'Santa Catalina' (4.9 g) and 'Heritage' (3.3 g). 'Santa Clara' $\left(\sim 6 \mathrm{ng} \mathrm{kg}^{-1} \mathrm{~s}^{-1}\right)$ fruits had the highest levels of ethylene production, followed by 'Santa Catalina', and 'Santa Teresa' with the lowest production. Regardless the cultivar, the fruit at the C5 stage always showed the highest ethylene production. Overall, compared with 'Heritage', these three new cultivars presented better fruit quality at harvest. The $0{ }^{\circ} \mathrm{C}$ was an adequate storage temperature for 'Santa Catalina' reaching storage potential of $20 \mathrm{~d}$ without soft fruits; therefore, it is recommended for fresh markets.
\end{abstract}

Key words: Ethylene production, quality, respiration rate, Rubus ideaus, storage potential.

\section{INTRODUCTION}

The red raspberry (Rubus ideaus L.) is a highly valued commodity due to its flavor, appearance (Palonen and Weber, 2019), and beneficial health properties provided by high levels of antioxidants (anthocyanins) (Fotschki et al., 2019). Several raspberry genetic programs have arisen worldwide, mainly focused on obtaining new cultivars with better morphological traits, higher quality standards for consumers and adaptations to growing conditions (Hall et al., 2009). However, one of the greatest concerns for researchers and the fruit industry is the high perishability of the raspberry fruit due to its rapid loss-of-firmness rate and, therefore, a limited storage life (Oduse and Cullen, 2012). Currently, Chile is the sixth largest producer of raspberries, with $32000 \mathrm{t}$ in 2019, and of these, $24714 \mathrm{t}$ were frozen fruit destined mainly to USA and Canada (ODEPA, 2020). The raspberry 'Heritage' has traditionally led the market, with $\sim 80 \%$ of the production destined for the frozen food industry (Leiva et al., 2017). 
Generally, postharvest studies have focused on how quality parameters change under certain storage conditions and what technologies can be applied to delay the senescence process. For instance, some of these studies have focused on fruit handling for firmness (Oduse and Cullen, 2012) and maintenance of the bright red color during storage, since a darker red color that appears during storage is less attractive to consumers (Stavang et al., 2015) and reflects that the fruit is more prone to decay (Zhang et al., 2020). Additionally, other studies have tried to establish an optimum maturity stage at harvest by using color as harvest index and to predict its evolution during storage for specific cultivars (Stavang et al., 2015). On the other hand, raspberry physiological parameters such as ethylene production and respiration rate have also been studied in attempts to understand raspberry behavior during storage.

The use of frozen storage is the most popular method for preserving raspberries (Bonat Celli et al., 2016), despite the concomitant loss of aroma, anthocyanins and other quality traits (de Ancos et al., 2000). Other alternatives that have emerged to control the limited storage life of raspberries include controlled or modified atmospheres and storage at $0{ }^{\circ} \mathrm{C}$, edible coatings, nanoactive films, and chemical compounds such as nitric oxide to maintain quality during storage (Shi et al., 2019). However, to establish a better postharvest strategy for raspberries, it is necessary to study in more detail the characteristics of the fruit and the evolution of its metabolic parameters once it has been harvested.

A few years ago, the Chilean Raspberry Breeding Program released three new primocane raspberry cultivars: Santa Catalina, Santa Clara and Santa Teresa. These cultivars were bred to develop plants with higher potential yields and fruit with better quality, for both the fresh and frozen markets. Currently, 'Santas' are being cultivated not only in Chile but also in other countries such as Spain, Italy, Australia and Mexico. Their high remontant behavior and low cold requirements during the growing season have allowed to expand the cultivation zone (Gambardella et al., 2016). The first objective of this research was to describe the fruit metabolism of the new varieties by studying the main physiological and quality parameters associated with different stages of maturity compared with 'Heritage', and the second objective was to investigate the storage potential of 'Santa Catalina' subjected to two contrasting temperatures. It should be noted that there is currently an expanding domestic fresh raspberry market, therefore, the postharvest behavior of these three new cultivars will allow the development of a more adequate handling of the fruit. In addition, this information will also serve for the management of the fruit before processing, considering that in most orchards the production of fruit is dualpurpose (frozen/fresh) depending on the commercialization opportunities. The parameters studied here will serve as a reference for further studies in other raspberry cultivars, since the storage potential has been addressed in very few studies reported in the literature.

\section{MATERIALS AND METHODS}

\section{Experiment 1. Determination of postharvest quality and physiological parameters}

Plant material. Raspberries (Rubus ideaus L.) of the Santa Catalina, Santa Clara, Santa Teresa and Heritage cultivars were obtained from an orchard located in Santo Domingo ( $\left.33^{\circ} 38^{\prime} 09^{\prime \prime} \mathrm{S}, 71^{\circ} 37^{\prime} 41^{\prime \prime} \mathrm{W}\right)$, Valparaíso Region, Chile. Fruit was obtained from the first-season shoots of plants established in November 2018 and grown in pots under a drip irrigation system. 'Heritage' was used as a control. All the cultivars were located in the same area and therefore subjected to the same commercial agronomic practices and environmental conditions. 'Santa Teresa' was harvested on 29 April, 'Santa Clara' on 22 May, 'Santa Catalina' on 28 May, and 'Heritage' on 10 August 2019. Raspberries of each cultivar were handpicked at three stages of maturity based on fruit color: pink (C3), commercial maturity, bright red (C4) and advanced maturity, dark red (C5) (Figure 1). For each cultivar, fruits at the three maturity stages were collected on the same day. For each stage, $\sim 400 \mathrm{~g}$ raspberries were harvested and separated into four replicates of $100 \mathrm{~g}$ each in $125 \mathrm{~g}$ clamshells. An additional 100 fruits of each stage were used for maturity analysis on the same day of harvest. All collected fruits were transported in thermoelectric coolers at $5-6{ }^{\circ} \mathrm{C}$ to the Laboratory of Postharvest Physiology at the Catholic University of Chile on the morning of harvest within $\sim 1.5 \mathrm{~h}$.

Maturity analysis. Upon arrival, a digital image was taken of five randomly selected raspberries from each stage of maturity (PowerShot G10, Canon, Tokyo, Japan), with a focal distance of $10 \mathrm{~mm}$, a 1/13 s exposure, a resolution of $4416 \times 3312$ pixels (JPEG images) and an sRGB color space. These images allowed the number of drupelets to be quantified. All other quality parameters were determined for 40 randomly selected raspberries at each maturity stage. Fruit 
Figure 1. Maturity stages of raspberry fruit based on color development. C1: White, C2: orange, C3: pink, C4: bright red (commercial harvest), C5: dark red (advanced maturity), C6: purple (overripe).

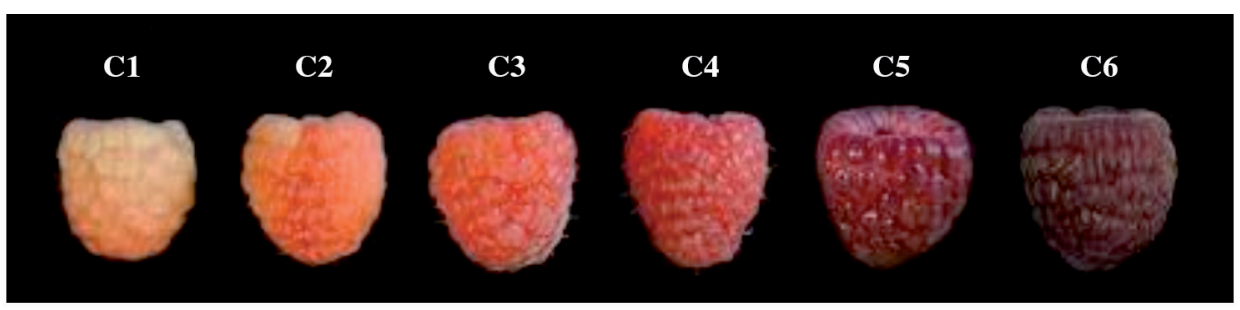

weight (g) was determined using a digital scale (ACB plus-600H, Adam Equipment Co. Ltd., Milton Keynes, UK). Fruit width and length $(\mathrm{mm})$ were evaluated with a $0.05 \mathrm{~mm}$ precision digital caliper (CD-6" ASX-B, Mitutoyo Sul Americana Ltda., Suzano, São Paulo, Brazil). Fruit color was determined with a colorimeter (CR-400 Chroma Meter, Konica Minolta Sensing Inc., Tokyo, Japan), and the values were expressed as lightness $\left(\mathrm{L}^{*}\right)$, chroma or intensity $\left(\mathrm{C}^{*}\right)$ and hue $\left(^{\circ}\right)$, where $0^{\circ}=$ red, $90^{\circ}=$ yellow, $180^{\circ}=$ green, and $270^{\circ}=$ blue. The soluble solids content $(\mathrm{SSC})$ was determined using a digital refractometer (Pal-1, Atago Co., Ltd., Tokyo, Japan) and expressed as percentage. Titratable acidity (TA) was measured using a pH meter (pH-211 Microprocessor, Hanna Instruments, Cluj-Napoca, Romania). The titrations were carried out with a $0.1 \mathrm{~N} \mathrm{NaOH}$ solution to a $\mathrm{pH}$ of 8.2, and the results were expressed as percentages of citric acid. Fruit firmness was assessed with a texturometer (TA.XT Plus, Stable Micro System, Godalming, UK) by compression test in each berry. Each raspberry was positioned with the receptacle cavity horizontal to the compression probe. Each berry, placed under a $30 \mathrm{~mm}$ diameter probe plate, was compressed at a final deformation of $80 \%$ by applying a force equivalent to $5 \mathrm{~N}$ at $2.0 \mathrm{~mm} \mathrm{~s}^{-1}$ test speed. The firmness of each fruit was calculated at $40 \%$ deformation, which corresponds to the energy $\left(\mathrm{N} \mathrm{mm}^{-1}\right)$ necessary to compress the berries at $40 \%$ of the initial height (Giovanelli et al., 2014). A force of $5 \mathrm{~N}$ was selected because preliminary work showed better separation of hand softening. Firmness was expressed in $\mathrm{N} \mathrm{mm}^{-1}$.

Ethylene production and respiration rate. On the day of harvest, $400 \mathrm{~g}$ raspberries (without the receptacle) per maturity stage (C3, C4 and C5) were divided into four replicates $100 \mathrm{~g}$ each and placed in $\sim 1 \mathrm{~L}$ plastic containers sealed under a flow-through system running overnight. The flow-through system and the four plastic containers per maturity stage were set at a room temperature of $20 \pm 1{ }^{\circ} \mathrm{C}$. Ethylene production and $\mathrm{CO}_{2}$ were measured the day after harvest, and these measurements were carried out twice a day (10:00 and 16:00 h) for $4 \mathrm{~d}$ for all cultivars. The measurements were stopped when fruit deteriorated (puree or juice drop conditions) or until the presence of any rot was visually detected. Ethylene concentration was determined by withdrawing a $5 \mathrm{~mL}$ sample from each container and immediately injected into a gas chromatograph (GC 8340, Fisons Instruments Inc., Beverly, Massachusetts, USA) equipped with a glass column ( $2 \mathrm{~m}$ long, 1/4" external and $2 \mathrm{~mm}$ internal diameter) filled with a porous polymer adsorbent matrix (80/100 mesh; Chromosorb 102, Thermo Electron Corporation, Milan, Italy) and a flame ionization detector (FID) at $250{ }^{\circ} \mathrm{C}$, with He used as the carrier gas. Ethylene production was expressed in $\mathrm{ng} \mathrm{kg}^{-1} \mathrm{~s}^{-1}$.

The respiration rate was determined with the flow-through system by flushing the $\sim 1 \mathrm{~L}$ sealed containers with air at approximately $8.92 \mathrm{~mL}$, according to the procedure described by Contreras and Beaudry (2013). The atmosphere in the containers was allowed enough time (overnight) to displace the volume inside each container at least 10 times before measurements were made. Samples of $16 \mathrm{~mL}$ air were taken from the outlet port and immediately injected in a portable MAP 4000 analyzer (Hitech Instruments Ltd., Luton, UK) with a zirconia sensor to measure $\mathrm{CO}_{2}$; it was expressed as $\mu \mathrm{g} \mathrm{kg} \mathrm{s}^{-1}$.

\section{Experiment 2. Storage potential of 'Santa Catalina'}

Plant material. Compared with the other 'Santa' cultivars, 'Santa Catalina' was chosen for this study since it is an early harvest cultivar, more productive and easier to handle for winter production. On 3 April 2019, 'Santa Catalina' was harvested from the same orchard mentioned above. Fruit, as in the first study, were hand-picked at maturity stages $\mathrm{C} 3, \mathrm{C} 4$ and $\mathrm{C} 5$, and collected in clamshells of $125 \mathrm{~g}$ ( $\sim 23$ raspberries). Forty-two clamshells were harvested for each stage of maturity, and 126 clamshells were harvested in total for the whole experiment. Once the fruit were collected 
in the clamshells, they were placed in thermoelectric coolers at $5-6^{\circ} \mathrm{C}$ and subsequently transported to the Laboratory of Postharvest Physiology at the Universidad Católica de Chile on the same day of harvest, within $\sim 1.5 \mathrm{~h}$. Once at the laboratory, the fruits were distributed into two groups per maturity: 21 clamshells were stored at $0{ }^{\circ} \mathrm{C}$ and the remaining 21 were stored at $4{ }^{\circ} \mathrm{C}$.

Initial and post storage evaluations. Initial quality parameters were assessed as previously described for 30 fruit per maturity stage. In addition, the weight loss was also evaluated for each maturity level and storage temperature. The initial weight of 15 raspberry fruits and their weight during each cold storage removal were recorded. Weight loss was calculated by subtracting the weight (g) at storage removal from the initial weight and expressed as a percentage.

Fruit was removed from $0{ }^{\circ} \mathrm{C}$ every $4 \mathrm{~d}$, as well as every $2 \mathrm{~d}$ for fruit stored at $4{ }^{\circ} \mathrm{C}$. Fruits under both temperatures were studied until they were no longer at an acceptable commercial quality or until the presence of visible rot. At each storage removal, the fruits of three $125 \mathrm{~g}$-clamshells were evaluated for their maturity stage, each being an independent replicate. In the post storage evaluations, the quality parameters evaluated were fruit color (colorimeter and color table), firmness (texturometer), and weight loss, and a digital image was collected. In addition, raspberries were subjected to a subjective texture rating scale (non-destructive) before the texturometer analysis (destructive) by gentle finger pressure. The subjective texture scale was included to relate to the texturometer results, and the ratings were divided into six different categories: very firm corresponded to > 62; firm, 50-62; semi firm, 41-49; soft, 38-40; very soft, 25-37; and puree, 0-24 $\mathrm{N} \mathrm{mm}^{-1}$ (Table 1).

\section{Statistical analysis}

For experiment 1 a completely randomized design was used. For experiment 2 , the experimental design was completely randomized in the treatment temperature assignment. ANOVA was performed using SPSS Statistics 25.0 software for Windows (IBM, Armonk, New York, USA). Tukey's test was used for multiple comparison analysis, with a $\mathrm{p} \leq 0.05$ level of significance for the case of firmness, weight and diameter, and $\mathrm{p} \leq 0.001$ for the evolution of color parameters.

\section{RESULTS}

\section{Experiment 1. Determination of postharvest quality and physiological parameters}

At harvest, 'Santa Teresa' presented the largest fruit, followed by 'Santa Clara', 'Santa Catalina' and 'Heritage' (Table 2). 'Santa Teresa' had an average weight of $6.5 \mathrm{~g}$, whereas 'Heritage' was $3.0 \mathrm{~g}$. The fruit weight increased on average by $1.9 \mathrm{~g}$ from $\mathrm{C} 4$ to $\mathrm{C} 5$ for 'Santa Teresa' and by $0.5 \mathrm{~g}$ for 'Heritage'. The size increase reflected by weight, width and length was always largest between the C4 and C5 stages for all cultivars. The firmest raspberry fruits were those of 'Santa Teresa', followed by 'Santa Catalina', 'Santa Clara' and 'Heritage'. Notably, 'Heritage' showed a sharp decline in fruit firmness throughout the developmental stages, presenting the lowest firmness value registered $\left(12 \mathrm{~N} \mathrm{~mm}^{-1}\right)$. Regarding the total sugar content, the highest value was detected in 'Santa Catalina', reaching a maximum of $10.6 \%$, and the lowest was detected in 'Heritage' $7.7 \%$. The color parameters showed that the fruits of 'Santa Clara' showed the lightest red color at C3 (31.7 hue) compared to the other cultivars, and 'Heritage' showed the darkest red color at C5 (17.8 hue).

With respect to physiological behavior, the respiration rate for all cultivars ranged between 8 and $30 \mu \mathrm{g} \mathrm{CO}_{2} \mathrm{~kg}^{-1} \mathrm{~s}^{-1}$ (Figure 2). Generally, C3, C4 and C5 displayed the same patterns for each cultivar, and their $\mathrm{CO}_{2}$ production corresponded with their maturity; i.e., the immature fruit presented higher respiration rates (stage C3), and highly mature fruit had lower respiration rates (stage C5). 'Santa Catalina' and 'Santa Clara' produced $\mathrm{CO}_{2}$ for $\sim 4 \mathrm{~d}$ at $20^{\circ} \mathrm{C}$, whereas 'Santa Teresa'

Table 1. Subjective texture scale in relation to the texturometer measurements of raspberries.

\begin{tabular}{cc}
\hline Firmness $\left(\mathrm{N} \mathrm{mm}^{-1}\right)$ & Texture category \\
\hline$>62$ & Very firm \\
$50-62$ & Firm \\
$41-49$ & Semi firm \\
$38-40$ & Soft \\
$25-37$ & Very soft \\
$0-24$ & Puree \\
\hline
\end{tabular}


Table 2. Fruit quality parameters of raspberry cultivars at harvest during the 2019 season.

\begin{tabular}{|c|c|c|c|c|c|c|c|c|c|c|c|c|}
\hline \multirow[b]{2}{*}{ Cultivar } & \multirow[b]{2}{*}{ Harvest $^{1}$} & \multirow[b]{2}{*}{ Weight } & \multirow[b]{2}{*}{$\begin{array}{l}\text { Fruit } \\
\text { width }\end{array}$} & \multirow[b]{2}{*}{$\begin{array}{l}\text { Fruit } \\
\text { length }\end{array}$} & \multirow[b]{2}{*}{$\begin{array}{l}\text { Drupelets/ } \\
\text { fruit }\end{array}$} & \multirow[b]{2}{*}{ Firmness } & \multirow[b]{2}{*}{ SSC } & \multirow[b]{2}{*}{ TA } & \multirow[b]{2}{*}{$\mathrm{SSC} / \mathrm{TA}$} & \multicolumn{3}{|c|}{ Color } \\
\hline & & & & & & & & & & $\mathrm{L}^{*}$ & $\mathrm{C}^{*}$ & $\begin{array}{c}\text { Hue } \\
\left({ }^{\circ}\right)\end{array}$ \\
\hline & & $\mathrm{g}$ & -1 & 1 & & $\mathrm{~N} \mathrm{~mm}^{-1}$ & $-\%$ & 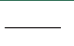 & & & & \\
\hline \multirow[t]{3}{*}{ Santa Catalina } & $\mathrm{C} 3$ & $3.9 \mathrm{~b}$ & $18.7 \mathrm{~b}$ & $23.1 \mathrm{a}$ & $58 \mathrm{~b}$ & $75.8 \mathrm{a}$ & $9.5 b$ & $1.7 \mathrm{~b}$ & $5.3 b$ & $39.1 \mathrm{a}$ & $41.5 \mathrm{a}$ & $34.7 \mathrm{a}$ \\
\hline & $\mathrm{C} 4$ & $4.0 \mathrm{~b}$ & $19.2 \mathrm{~b}$ & $23.1 \mathrm{a}$ & $62 a$ & $51.9 \mathrm{~b}$ & $10.6 \mathrm{a}$ & $1.9 \mathrm{a}$ & $5.4 \mathrm{~b}$ & $31.7 \mathrm{~b}$ & $34.8 \mathrm{~b}$ & $27.8 \mathrm{~b}$ \\
\hline & $\mathrm{C} 5$ & $4.9 \mathrm{a}$ & $20.2 \mathrm{a}$ & $23.4 \mathrm{a}$ & $63 a$ & $42.3 b$ & $10.4 \mathrm{a}$ & $1.0 \mathrm{c}$ & $10.1 \mathrm{a}$ & $27.2 \mathrm{c}$ & $26.9 \mathrm{c}$ & $23.6 \mathrm{c}$ \\
\hline \multirow[t]{3}{*}{ Santa Clara } & $\mathrm{C} 3$ & $3.7 \mathrm{c}$ & $18.8 \mathrm{c}$ & $20.3 b$ & $81 b$ & $66.7 \mathrm{~b}$ & $9.6 \mathrm{a}$ & $1.9 \mathrm{a}$ & $5.0 \mathrm{~b}$ & $35.9 \mathrm{a}$ & $39.9 a$ & $31.7 \mathrm{a}$ \\
\hline & $\mathrm{C} 4$ & $4.3 b$ & $20.4 b$ & $22.0 \mathrm{a}$ & $76 c$ & $48.0 \mathrm{c}$ & $9.7 \mathrm{a}$ & $1.4 \mathrm{~b}$ & $6.6 \mathrm{a}$ & $33.0 \mathrm{~b}$ & $36.0 \mathrm{~b}$ & $28.7 \mathrm{~b}$ \\
\hline & C5 & $5.3 \mathrm{a}$ & $21.6 \mathrm{a}$ & $23.3 \mathrm{a}$ & $87 \mathrm{a}$ & $34.8 \mathrm{a}$ & $9.8 \mathrm{a}$ & $1.4 \mathrm{~b}$ & 7.1a & $27.5 \mathrm{c}$ & $26.1 \mathrm{c}$ & $22.2 \mathrm{c}$ \\
\hline \multirow[t]{3}{*}{ Santa Teresa } & $\mathrm{C} 3$ & $5.8 \mathrm{~b}$ & $21.8 \mathrm{~b}$ & $26.4 \mathrm{a}$ & $78 \mathrm{a}$ & $92.2 \mathrm{a}$ & $9.3 \mathrm{a}$ & $2.3 \mathrm{a}$ & $3.9 \mathrm{a}$ & $36.7 \mathrm{a}$ & $38.3 \mathrm{a}$ & $33.4 \mathrm{a}$ \\
\hline & $\mathrm{C} 4$ & $6.0 \mathrm{~b}$ & $22.6 b$ & $26.4 \mathrm{a}$ & $73 b$ & $68.8 \mathrm{~b}$ & $9.8 \mathrm{a}$ & $2.1 \mathrm{~b}$ & $4.6 \mathrm{a}$ & $28.8 \mathrm{~b}$ & $28.3 \mathrm{~b}$ & $22.8 b$ \\
\hline & $\mathrm{C} 5$ & $7.9 \mathrm{a}$ & $24.7 \mathrm{a}$ & $28.3 \mathrm{a}$ & $79 a$ & $55.8 \mathrm{a}$ & $9.7 \mathrm{a}$ & $2.0 \mathrm{~b}$ & $4.7 \mathrm{a}$ & $25.8 \mathrm{c}$ & $22.6 \mathrm{c}$ & $19.8 \mathrm{c}$ \\
\hline \multirow[t]{3}{*}{ Heritage } & $\mathrm{C} 3$ & $3.0 \mathrm{a}$ & $19.7 \mathrm{c}$ & $19.3 b$ & $90 a$ & $57.6 \mathrm{a}$ & $7.7 b$ & $2.4 \mathrm{a}$ & $3.0 \mathrm{~b}$ & $40.4 \mathrm{a}$ & $44.1 \mathrm{a}$ & $32.9 \mathrm{a}$ \\
\hline & $\mathrm{C} 4$ & $2.8 \mathrm{a}$ & $19.0 \mathrm{~b}$ & $19.7 \mathrm{a}$ & $88 \mathrm{~b}$ & $41.1 \mathrm{~b}$ & $8.2 \mathrm{a}$ & $2.1 \mathrm{~b}$ & $3.8 \mathrm{a}$ & $32.0 \mathrm{~b}$ & $34.0 \mathrm{~b}$ & $23.7 b$ \\
\hline & C5 & $3.3 \mathrm{a}$ & $20.5 \mathrm{a}$ & $18.9 \mathrm{c}$ & $85 c$ & $12.0 \mathrm{c}$ & $8.5 \mathrm{a}$ & $2.6 \mathrm{a}$ & $2.9 \mathrm{~b}$ & $27.0 \mathrm{~b}$ & $22.7 \mathrm{c}$ & $17.8 \mathrm{c}$ \\
\hline
\end{tabular}

Values are means \pm standard errors of four replicates.

SSC: Soluble solids content; TA: titratable acidity expressed as percent citric acid.

${ }^{1}$ Maturity stages: C3: pink, C4: bright red (commercial harvest), C5: dark red (advanced maturity).

and 'Heritage' produced $\mathrm{CO}_{2}$ for $3 \mathrm{~d}$. These two last cultivars, Santa Teresa and Heritage, showed similar respiration patterns of approximately 8-10 $\mu \mathrm{g} \mathrm{CO}_{2} \mathrm{~kg}^{-1} \mathrm{~s}^{-1}$. In addition, 'Santa Teresa' showed rot incidence after $76 \mathrm{~h}$, which increased $\mathrm{CO}_{2}$ production to rates even higher than those at harvest. On the other hand, the ethylene production rate was always the highest at stage C5 and lowest in the less mature fruit at C3 (Figure 2). Santa Clara was the cultivar with the highest ethylene production, reaching approximately $6 \mathrm{ng} \mathrm{kg}^{-1} \mathrm{~s}^{-1}$ on the second day after harvest, followed by 'Santa Catalina', which reached nearly $4 \mathrm{ng} \mathrm{kg}^{-1} \mathrm{~s}^{-1}$, and 'Santa Teresa' and 'Heritage', which reached 2-3 $\mathrm{ng} \mathrm{kg}^{-1} \mathrm{~s}^{-1}$. The C5 stage always presented a sharpest decline in ethylene production, evidencing that the fruits at this stage reached senescence first compared to those at C3 and C4. 'Santa Teresa' and 'Heritage' behaved similarly to that observed for the respiration rate; both cultivars showed similar production patterns of ethylene.

\section{Experiment 2. Storage potential of 'Santa Catalina'}

The initial evaluation of quality parameters at harvest is presented in Table 3. Quality parameters such as firmness, SSC, TA and color evidenced differences in maturity during the fruit development at the C3, C4 and C5 stages. Morphological parameters such as weight, width and length diameters, and number of drupelets did not show differences between stages $\mathrm{C} 4$ and C5, and even fruits at C5 presented lower values than did those at C4.

Generally, the storage potential of a fruit is determined by the loss-of-firmness rate. Hence, $0{ }^{\circ} \mathrm{C}$ preserved fruit firmness of 'Santa Catalina' better than $4{ }^{\circ} \mathrm{C}$ did in all developmental stages (Figure 3). Therefore, the main difference in storage life is governed by the physiological stage; that is, the more immature the raspberry is (C3), the longer the storage life. For instance, fruits at $\mathrm{C} 3 \mathrm{had}$ a storage life of nearly $20 \mathrm{~d}$ at $0{ }^{\circ} \mathrm{C}$, whereas at $4{ }^{\circ} \mathrm{C}$, fruits of $\mathrm{C} 3$ had a storage life of $10 \mathrm{~d}$, considering $40 \mathrm{~N} \mathrm{~mm}$ as the limit for soft fruit (Table 1). On the other hand, C5 always involved soft fruit from the harvest, having a greater proportion of very soft and puree fruit throughout storage, which are not suitable for fresh markets.

Table 3. Fruit quality parameters of 'Santa Catalina' raspberry at harvest during the 2019 season.

\begin{tabular}{|c|c|c|c|c|c|c|c|c|c|c|c|}
\hline \multirow[b]{2}{*}{ Harvest $^{1}$} & \multirow[b]{2}{*}{ Weight } & \multirow[b]{2}{*}{$\begin{array}{l}\text { Fruit } \\
\text { width }\end{array}$} & \multirow[b]{2}{*}{$\begin{array}{l}\text { Fruit } \\
\text { length }\end{array}$} & \multirow[b]{2}{*}{$\begin{array}{l}\text { Drupelets/ } \\
\text { fruit }\end{array}$} & \multirow[b]{2}{*}{ Firmness } & \multirow[b]{2}{*}{ SSC } & \multirow[b]{2}{*}{$\mathrm{TA}$} & \multirow[b]{2}{*}{$\mathrm{SSC} / \mathrm{TA}$} & \multicolumn{3}{|c|}{ Color } \\
\hline & & & & & & & & & $\mathrm{L}^{*}$ & $\mathrm{C}^{*}$ & $\begin{array}{l}\text { Hue } \\
\left({ }^{\circ}\right)\end{array}$ \\
\hline & $\mathrm{g}$ & - & - & & $\mathrm{N} \mathrm{mm}$ & - & - & & & & \\
\hline $\mathrm{C} 3$ & $3.2 \mathrm{~b}$ & $17.9 \mathrm{~b}$ & $20.8 \mathrm{a}$ & $61 \mathrm{a}$ & $70.6 a$ & $8.3 b$ & $2.5 \mathrm{a}$ & $3.3 b$ & $39.6 \mathrm{a}$ & $40.5 \mathrm{a}$ & $31.6 \mathrm{a}$ \\
\hline $\mathrm{C} 4$ & $4.5 \mathrm{a}$ & $20.7 \mathrm{a}$ & $23.8 \mathrm{a}$ & $62 a$ & $44.9 \mathrm{~b}$ & $9.0 \mathrm{a}$ & $2.0 \mathrm{~b}$ & $4.5 \mathrm{a}$ & $31.3 \mathrm{~b}$ & $29.9 b$ & $24.5 b$ \\
\hline $\mathrm{C} 5$ & $4.4 \mathrm{ab}$ & $19.7 \mathrm{a}$ & $22.7 \mathrm{a}$ & $55 \mathrm{~b}$ & $32.4 b$ & $9.2 \mathrm{a}$ & $1.9 \mathrm{~b}$ & $4.9 \mathrm{a}$ & $29.1 \mathrm{c}$ & $25.3 \mathrm{~b}$ & $22.6 b$ \\
\hline
\end{tabular}

Values are means \pm standard errors of three replicates.

SSC: Soluble solids content; TA: titratable acidity expressed as percent citric acid.

'Maturity stages: C3: pink, C4: bright red (commercial harvest), C5: dark red (advanced maturity). 
Figure 2. Respiration rate and ethylene production patterns of raspberry fruit cultivars Santa Catalina, Santa Clara, Santa Teresa and Heritage stored at $20^{\circ} \mathrm{C}$ after harvest.
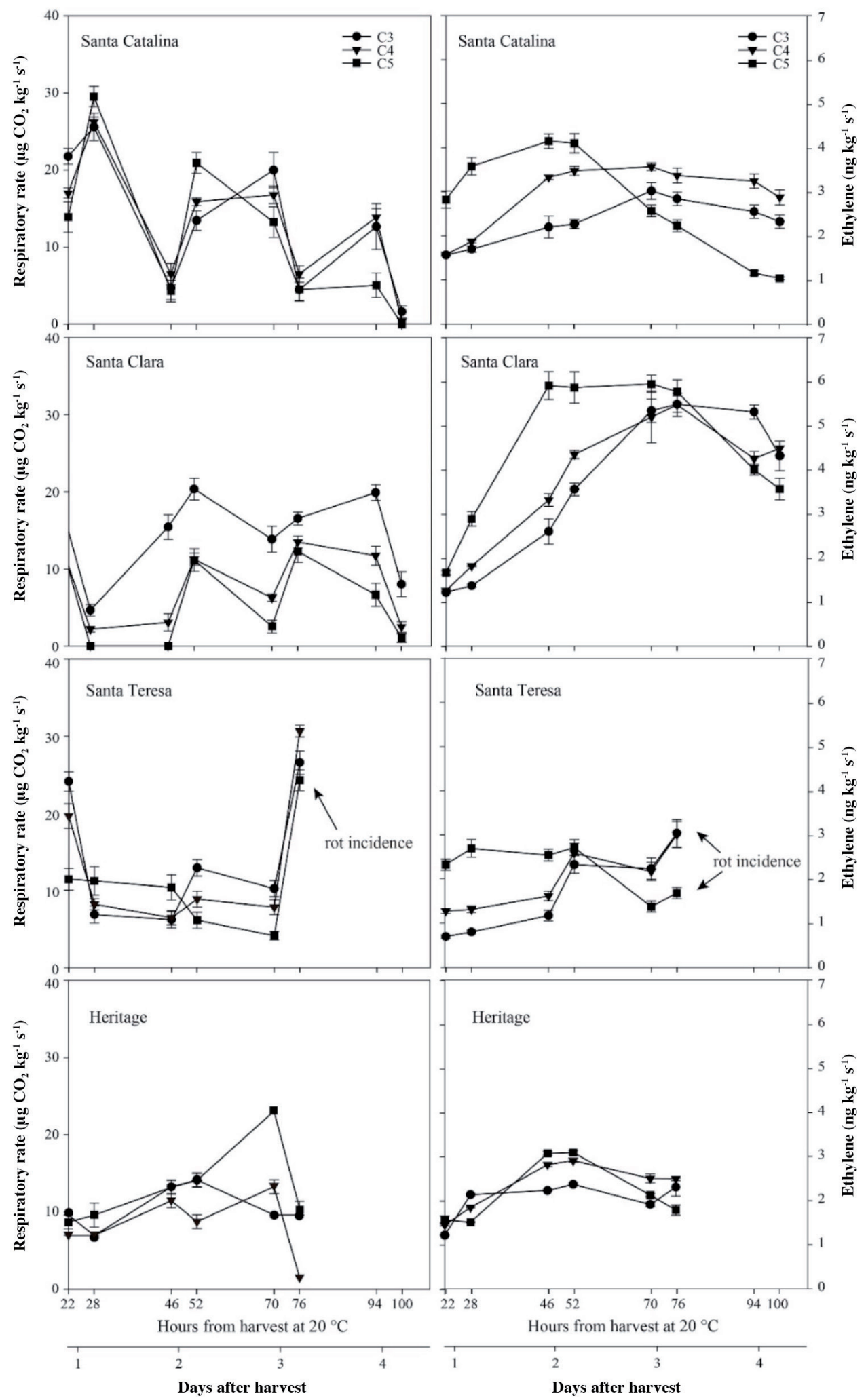

The fruits were measured twice a day with a flow-through system. Each value indicates the mean of four biological replicates \pm standard error. Maturity stages C3: pink, C4: bright red (commercial harvest), and C5: dark red (advanced maturity). 
Figure 3. Firmness of 'Santa Catalina' raspberry fruit at the $\mathrm{C3}, \mathrm{C} 4$ and $\mathrm{C5}$ phenological stages during storage at 0 and $4{ }^{\circ} \mathrm{C}$.

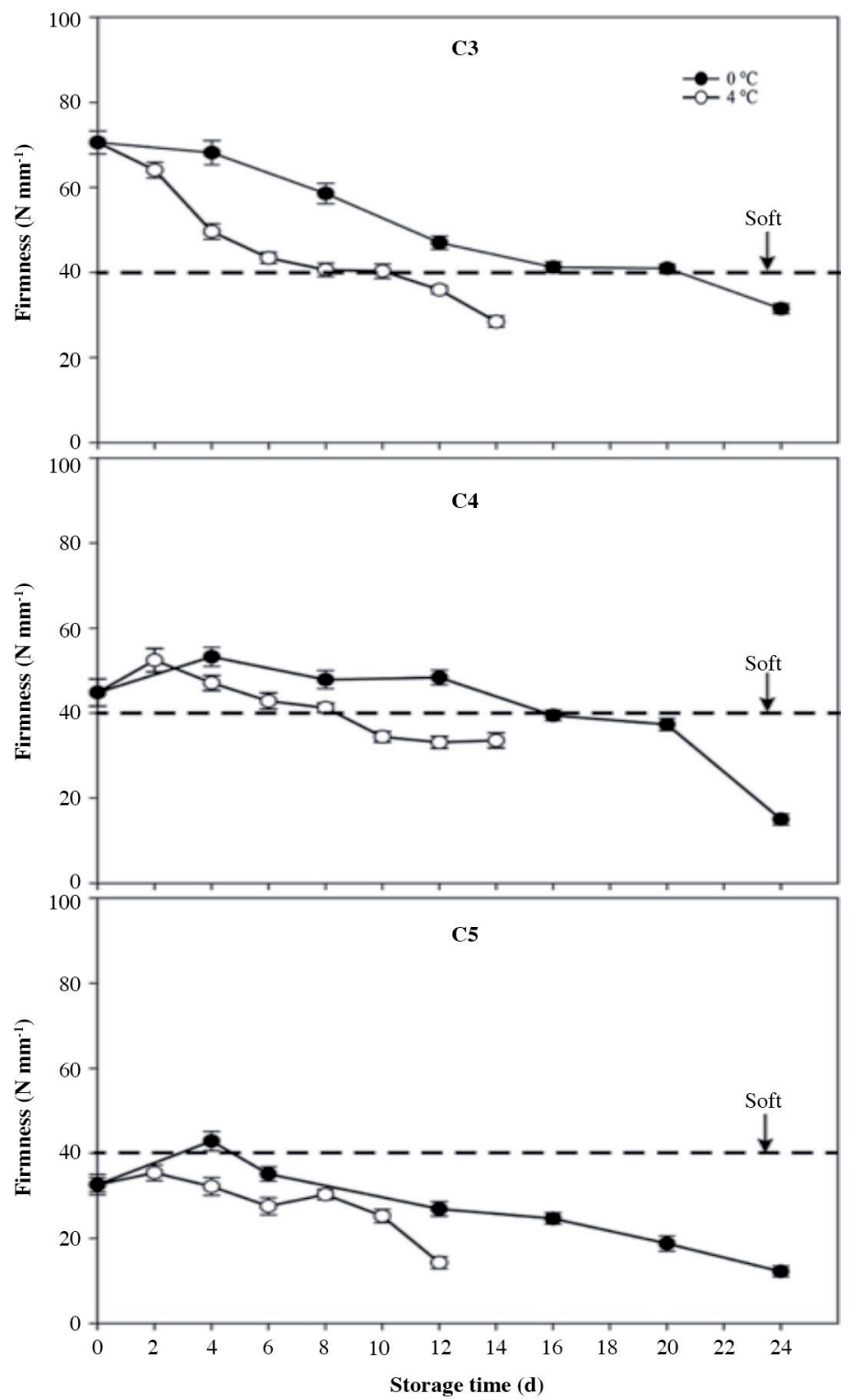

Maturity stages C3: pink, C4: bright red (commercial harvest), and C5: dark red (advanced maturity).

The texture categories of fruits inside the clamshells during storage are shown in Figure 4. The loss-of-firmness pattern is similar for each stage at 0 or $4{ }^{\circ} \mathrm{C}$; however, the loss-of-firmness rate differs between temperatures. For instance, until day 4 , both temperatures were able to maintain similar texture proportions inside the clamshells, and then there was a decline at $4{ }^{\circ} \mathrm{C}$, showing a greater proportion of soft fruit. Raspberries kept at $0{ }^{\circ} \mathrm{C}$ showed a storability potential of $24 \mathrm{~d}$ compared with the potential of those stored at $4{ }^{\circ} \mathrm{C}$, which was $14 \mathrm{~d}$ for $\mathrm{C} 3$ and $\mathrm{C} 4$ fruits and $12 \mathrm{~d}$ for $\mathrm{C} 5$ fruits. The best storage potential was shown by $\mathrm{C} 3$ fruits at $0{ }^{\circ} \mathrm{C}$; this potential reached $12 \mathrm{~d}$ of storage with $<10 \%$ soft fruit, whereas at $4{ }^{\circ} \mathrm{C}$, it reached $6 \mathrm{~d}$ of storage with the same proportion of soft fruit. On average, $\sim 8 \mathrm{~d}$ of storage are potentially lost for every increase in the stage of maturity, considering that $50 \%$ of the clamshells had soft fruit.

Color changes during storage were similar regardless of the storage temperature, but the rate of change was faster at $4{ }^{\circ} \mathrm{C}$. For instance, fruit at $0{ }^{\circ} \mathrm{C}$ reached the darkest red at day 24 , whereas fruit at $4{ }^{\circ} \mathrm{C}$ reached the darkest red at day 14 . The fruits at both temperatures presented an average hue value of $\sim 20^{\circ}$ at the end of the storage time (data not shown). 
Figure 4. Raspberry classification according to each texture category of fruits inside clamshells during storage at 0 and $4{ }^{\circ} \mathrm{C}$.

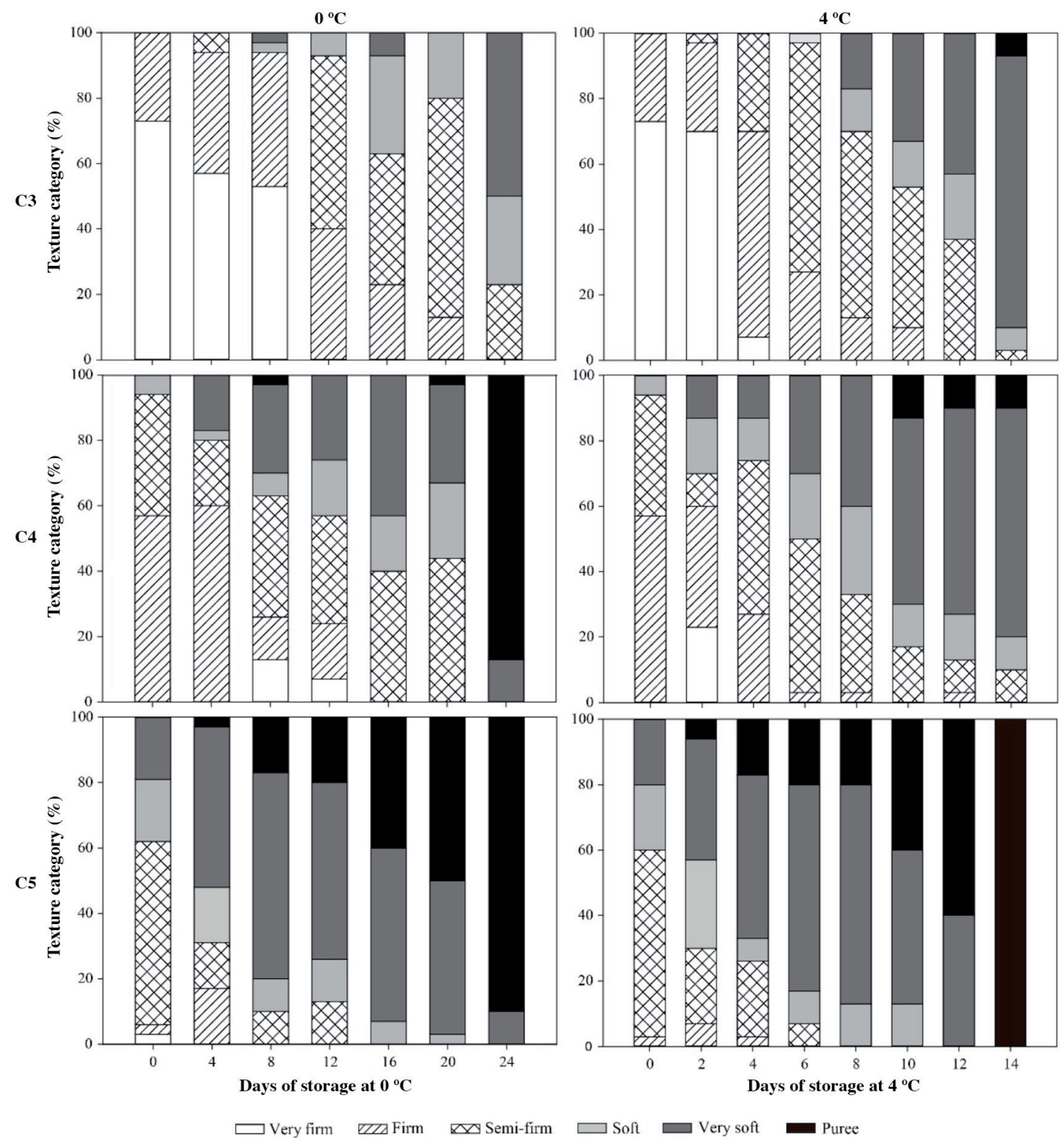

Maturity stages C3: pink, C4: bright red (commercial harvest), and C5: dark red (advanced maturity).

\section{DISCUSSION}

The fruit quality and physiology at harvest of new raspberry cultivars were determined and compared to those of 'Heritage'. With respect to quality parameters, the results for fruit size parallel those found by Gambardella et al. (2016), where 'Santa Teresa' presented the largest fruit size and 'Heritage' presented the smallest. In terms of SSC and TA, the fruits of 'Santa Teresa' and 'Heritage' showed low sugar/acid ratios. It is known that the sugar/acid ratio of 'Heritage' fruits is usually low, making the fruits of this cultivar more suitable for frozen processing or for consumers with acidophilus preferences (Yang et al., 2020). Conversely, the highest ratio was shown by 'Santa Catalina' and 'Santa Clara', suggesting that these cultivars may be well suited for the fresh market due to their higher sugar content, whereas 'Santa Teresa' might be used 
for both, frozen and fresh markets. In our study, the maturity stage determined the amount of sugars and TA, where sugars increased at every phenological stage, but the TA decreased, coinciding with other raspberry studies where the SSC increased and where the TA decreased as the fruits matured (Perkins-Veazie and Nonnecke, 1992). There has been proposed a minimum SSC and maximum TA value for acceptable flavor in raspberries: $8 \%$ SCC and 0.8\% TA (Kader, 2002). Raspberries have been reported to have fructose as their main soluble sugar, followed by glucose and then sucrose (Kafkas et al., 2008; Ali et al., 2011). Fructose and glucose are usually high in raspberries due to sucrose hydrolysis during mature stages (Ali et al., 2011). The concentration of fructose has been identified as a relevant characteristic in raspberry fruits used as dessert (Kafkas et al., 2008) because of its highest sweetness perception.

The respiration patterns of the different raspberry cultivars showed a decreasing trend while the fruits ripened. This behavior coincides with the non-climacteric fruit behavior and with the results of previous studies on the respiration rate of raspberries (Perkins-Veazie and Nonnecke, 1992). In addition, 'Heritage' fruits presented among the lowest respiration rates observed, which has also been reported in comparisons with fruits of other raspberry cultivars (Perkins-Veazie and Nonnecke, 1992). Generally, high respiration rates are associated with high perishability and poor quality after harvest. Raspberries have been reported to have high respiration rates with an average production of 20$40 \mathrm{mg} \mathrm{CO} \mathrm{kg}^{-1} \mathrm{~h}^{-1}\left(5-12 \mu \mathrm{g} \mathrm{CO} \mathrm{kg}^{-1} \mathrm{~s}^{-1}\right)$ at $20^{\circ} \mathrm{C}$, and a high respiration quotient ( $\mathrm{RQ}=1.67$ ) (Kader, 2002; Giovanelli et al., 2014), with some values reportedly surpassing $150 \mathrm{mg} \mathrm{CO}_{2} \mathrm{~kg}^{-1} \mathrm{~h}^{-1}$ at $20^{\circ} \mathrm{C}$ (Fuentes et al., 2015) or at $10{ }^{\circ} \mathrm{C}$ for 'Heritage' (Monsalve et al., 2018). These respiration rate values limit their storage life to $<2 \mathrm{wk}$, specifically to 3-6 d at $20{ }^{\circ} \mathrm{C}$. This average respiration rate coincides with the rates obtained from 'Santa' fruits, where the $\mathrm{CO}_{2}$ production ranged 10-20 $\mu \mathrm{g} \mathrm{CO}_{2} \mathrm{~kg}^{-1} \mathrm{~s}^{-1}$ and, in some cases, reached $30 \mu \mathrm{g} \mathrm{CO}_{2} \mathrm{~kg}^{-1} \mathrm{~s}^{-1}$. With respect to ethylene, raspberry fruits are classified as being producers of low amounts of ethylene and exhibiting low sensitivity to ethylene, with an average production of 0.1-1.0 $\mu \mathrm{L} \mathrm{C}_{2} \mathrm{H}_{4} \mathrm{~kg}^{-1} \mathrm{~h}^{-1}$ (Kader, 2002), $<10 \mu \mathrm{L} \mathrm{C}_{2} \mathrm{H}_{4} \mathrm{~kg}^{-1} \mathrm{~h}^{-1}$ for 'Heritage' at $20{ }^{\circ} \mathrm{C}$ (Fuentes et al., 2015), or 3-4 $\mu \mathrm{L} \mathrm{C}_{2} \mathrm{H}_{4} \mathrm{~kg}^{-1} \mathrm{~h}^{-1}$ at $10^{\circ} \mathrm{C}$ (Monsalve et al., 2018). Ethylene production showed clear differences in the shelf life of the fruits of the cultivars studied; for instance, C5 fruits always produced relatively high levels of ethylene but also rapidly decreased their production, reflecting the fruit senescence stage. This fact could suggest that fruits at the $\mathrm{C} 3$ and C4 stages have a better postharvest shelf life than fruits at C5. Since the raspberry is a non-climacteric fruit, the effect of ethylene on quality traits is not relevant; for instance, Perkins-Veazie and Nonnecke (1992) reported that the SSC and TA were independent of ethylene levels in 'Heritage'. 'Santa Catalina' and 'Santa Clara' showed a similar metabolism in terms of $\mathrm{CO}_{2}$ and ethylene production rates (Figure 2). Likewise, 'Santa Teresa' and 'Heritage' were similar, suggesting that the postharvest characteristics in terms of storage potential of 'Santa Teresa' may be similar to 'Heritage'. The fruits of these two cultivars produced ethylene and $\mathrm{CO}_{2}$ for $\sim 3 \mathrm{~d}$, after which 'Heritage' showed symptoms of senescence, and 'Santa Teresa' was showing signs of decay. It has been reported that raspberry storage life is limited by decay caused by several fungi, such as Botrytis spp., Rhizopus spp., and Cladosporium spp. (Wang, 2003). However, we do not overlook the possibility that 'Santa Teresa' may have an increased storage potential if infection is reduced during fruit development.

Softening and decay are the most sensitive parameters for raspberry deterioration, followed by the percentage of damaged berries, weight loss, and odor changes (Giovanelli et al., 2014). 'Santa Catalina' raspberry storage life was largely limited by a decrease in firmness rather than the presence of rot. Previous studies on mechanical resistance to a force have shown that raspberry fruit have an overall mechanical resistance 'exceedingly low', and interestingly, the resistance to separation of the receptacle is two to four times larger than the axial and transversal resistance of the fruit (Reynoso and Michelis, 1994). In addition, data in the literature report variable firmness values for raspberries due to the use of different equipment, and the lack of an international standard method available to determine this quality trait (Giongo et al., 2019). Regardless, the firmness of the raspberries declined during storage at all maturity stages and temperature conditions. Our values were higher than those reported by Giovanelli et al. (2014), likely because we used a 5 $\mathrm{N}$ load instead of a $10 \mathrm{~N}$ load, and they used another cultivar (Erika), whose fruits were picked at the commercial ripeness stage in all their experiments; these values were comparable to our values only measured at the C5 stage. After evaluating 20 raspberry cultivars, Giongo et al. (2019) classified them into two groups: the first group had a dramatic decrease in firmness as the fruit ripened (like the 'Heritage' fruits), and the second group had a more stable firmness during ripening, but the initial force was lower. These data suggest that 'Santa Catalina' belongs to the first group, given the sharp decrease in initial fruit firmness at the $\mathrm{C} 4$ and $\mathrm{C} 5$ stages. Thus, this trait behavior of raspberries suggests a genetic control similar to what has been found in other Rosaceae species (Giongo et al., 2019). 


\section{CONCLUSIONS}

This work demonstrated the quality characteristics of three new Chilean raspberry cultivars ('Santa Catalina', 'Santa Clara' and 'Santa Teresa') compared to a traditional cultivar such as Heritage. The quality parameters were directly related to the physiological stage, where the less mature raspberries (C3) had a longer shelf life and were firmer. Therefore, pink (C3) and bright red (C4) raspberries are the recommended stages for harvesting the fruits of these cultivars and thus ensure better postharvest behavior. On the other hand, fruits of 'Santa Catalina' had better storage potential at $0{ }^{\circ} \mathrm{C}$ than at $4{ }^{\circ} \mathrm{C}$, reaching $20 \mathrm{~d}$ of cold storage without soft fruits. The storage potential of 'Santa Catalina' fruits was also determined by the maturity stage, as previously noted. 'Santa Catalina' may represent a good commercialization choice for the fresh market, where prices for producers are higher than those for the frozen market.

\section{ACKNOWLEDGEMENTS}

We gratefully acknowledge the financial support of the 16PTECFS-66641 Project "Raspberry Breeding Program”, PTECCorfo (Chilean Agency).

\section{REFERENCES}

Ali, L., Svensson, B., Alsanius, B., and Olsson, M. 2011. Late season harvest and storage of Rubus berries - Major antioxidant and sugar levels. Scientia Horticulturae 129(3):376-381. doi:10.1016/j.scienta.2011.03.047.

Bonat Celli, G., Ghanem, A., and Su-Ling Brooks, M. 2016. Influence of freezing process and frozen storage on the quality of fruits and fruit products. Food Reviews International 32:280-304. https://doi.org/10.1080/87559129.2015.1075212.

Contreras, C., and Beaudry, R. 2013. Lipoxygenase-associated apple volatiles and their relationship with aroma perception during ripening. Postharvest Biology and Technology 82:28-38. https://doi.org/10.1016/j.postharvbio.2013.02.006.

de Ancos, B., Ibañez, E., Reglero, G., and Cano, P. 2000. Frozen storage effects on anthocyanins and volatile compounds of raspberry fruit. Journal of Agricultural and Food Chemistry 48:873-879. https://doi.org/10.1021/jf990747c.

Fotschki, B., Juśkiewicz, J., Jurgoński, A., Kosmala, M., Milala, J., Zduńczyk, Z., et al. 2019. Grinding levels of raspberry pomace affect intestinal microbial activity, lipid and glucose metabolism in Wistar rats. Food Research International 120:399-406. https://doi.org/10.1016/j.foodres.2019.03.014.

Fuentes, L., Monsalve, L., Morales-Quintana, L., Valdenegro, M., Martínez, J.P., Defilippi, B., et al. 2015. Differential expression of ethylene biosynthesis genes in drupelets and receptacle of raspberry (Rubus idaeus). Journal of Plant Physiology 179:100-105. http://dx.doi.org/10.1016/j.jplph.2015.02.005.

Gambardella, M., Bañados, P., Sánchez, S., Grez, J., Contreras, E., and Sagredo, B. 2016. New raspberry cultivars for Chile: first releases from the local breeding program. Acta Horticulturae 1117:19-24. doi:10.17660/ActaHortic.2016.1117.4.

Giongo, L., Ajelli, M., Poncetta, P., Ramos-García, M., Sambo, P., and Farneti, B. 2019. Raspberry texture mechanical profiling during fruit ripening and storage. Postharvest Biology and Technology 149:177-186. https://doi.org/10.1016/j.postharvbio.2018.11.021.

Giovanelli, G., Limbo, S., and Buratti, S. 2014. Effects of new packaging solutions on physico-chemical, nutritional and aromatic characteristics of red raspberries (Rubus idaeus L.) in postharvest storage. Postharvest Biology and Technology 98:72-81. https://doi.org/10.1016/j.postharvbio.2014.07.002.

Hall, H., Hummer, K.E., Jamieson, A., Jennings, S.N., and Weber, C. 2009. Raspberry breeding and genetics. In Janick, J. (ed.) Plant Breeding Reviews Vol. 32. Wiley-Blackwell, Hoboken, New Jersey, USA.

Kader, A. 2002. Postharvest biology and technology: an overview. p. 39-48. In Kader, A. (ed.) Postharvest technology of horticultural crops. University of California Agriculture and Natural Resources, Oakland, California, USA.

Kafkas, E., Özgen, M., Özoğul, Y., and Türemis, N. 2008. Phytochemical and fatty acid profile of selected red raspberry cultivars: a comparative study. Journal of Food Quality 31:67-78.

Leiva, C., Schmidt, C., y Gajardo, G. 2017. Manual técnico productivo y económico para la producción de frambuesa en la region del Biobío, bajo condición actual y clima proyectado al 2030. CIREN N 204. p. 20-21. Centro de Información de Recursos Naturales (CIREN), Santiago, Chile.

Monsalve, L., Ayala-Raso, A., Bernales, M., Valdenegro, M., Defilippi, B., González-Agüero, M., et al. 2018. Dataset on quality and physiological changes of raspberry fruit during their development and under auxin in-vitro assay. Data in Brief 21:1521-1525. http://doi.org/10.1016/j.dib.2018.10.089.

ODEPA. 2020. Avance por grupo de productos. Oficina de Estudios y Políticas Agrarias (ODEPA), Santiago, Chile. Available at https://www.odepa.gob.cl/avance-por-grupos-de-productos (accessed 27 February 2020). 
Oduse, K.A., and Cullen, D. 2012. An investigation into the fruit firmness properties of some progeny and cultivars of red raspberry (Rubus idaeus). Journal of Environmental Science, Toxicology, and Food Technology 1:4-12. doi:10.9790/2402-0160412.

Palonen, P., and Weber, C. 2019. Fruit color stability, anthocyanin content, and shelf life were not correlated with ethylene production rate in five primocane raspberry genotypes. Scientia Horticulturae 247:9-16. https://doi.org/10.1016/j.scienta.2018.11.0880.

Perkins-Veazie, P., and Nonnecke, G. 1992. Physiological changes during ripening of raspberry fruit. HortScience 27:331-333.

Reynoso, R., and Michelis, A. 1994. Parameters affecting freezing, storage and transport of individually frozen Schöeneman raspberries. International Journal of Refrigeration 17:209-203. https://doi.org/10.1016/0140-7007(94)90021-3.

Shi, K., Liu, Z., Wang, J., Zhu, S., and Huang, D. 2019. Nitric oxide modulates sugar metabolism and maintains the quality of red raspberry during storage. Scientia Horticulturae 256:108611. https://doi.org/10.1016/j.scienta.2019.108611.

Stavang, J., Freitag, S., Foito, A., Verrall, S., Heide, O., Stewart, D., et al. 2015. Raspberry fruit quality changes during ripening and storage assessed by colour, sensory evaluation and chemical analyses. Scientia Horticulturae 195:216-225. http://dx.doi.org/10.1016/j.scienta.2015.08.045.

Wang, C. 2003. Maintaining postharvest quality of raspberries with natural volatile compounds. International Journal of Food Science \& Technology 38:869-875

Yang, J., Cui, J., Chen, J., Yao, J., Hao, Y., Fan, Y., et al. 2020. Evaluation of physicochemical properties in three raspberries (Rubus idaeus) at five ripening stages in northern China. Scientia Horticulturae 263:109-146. https://doi.org/10.1016/j.scienta.2019.109146.

Zhang, X., Gao, Z., Zhang, X., Bai, W., Zhang, L., Pei, H., et al. 2020. Control effects of Bacillus siamensis G-3 volatile compounds on raspberry postharvest diseases caused by Botrytis cinerea and Rhizopus stolonifer. Biological Control 141:104135. https://doi.org/10.1016/j.biocontrol.2019.104135. 